availability of rewarding septal and hypothalamic stimulation of bar-pressing for food under conditions of deprivation. Journal of Comparative \& Physiological Psychology,1965, 60, 158-161.

THOMPSON, T., \& BLOOM, W. Aggressive behavior and extinction-induced response rate increase. Psychonomic Science, 1966, 5, 335-336.

\title{
Effects of the marihuana homologue, pyrahexyl, on a conditioned emotional response
}

\author{
ERNEST L. ABEL, University of Toronto, \\ Toronto, Ont., Canada
}

A single injection into adult male rats of the marihuana homologue, pyrahexyl, disrupted the suppressive effect in a CER situation of a stimulus previously paired with shock. The latency to resume the operant in the pyrahexyl-injected $S$ s was one-half that shown by control animals. Three possible explanations for the effect are discussed.

Early research dealing with marihuanatype substances was hampered by the fact that material of fixed and known strength could not be obtained. This difficulty was overcome when Adams, Loewe, Jelinek, \& Wolff (1941) succeeded in isolating tetrahydrocannabinol as the active ingredient in marihuana (cannabis sativa). Once isolated, synthetic tetrahydrocannabinols could be prepared and one of the many derivatives thus produced was pyrahexyl (synhexyl). Although it has been available since 1943 (Adams, Haefenist, \& Loewe, 1943), there has been a paucity of research using this substance, and what research there is suffers from a grievous lack of experimental control. For some odd reason, experiments dealing with the behavioral effects of tetrahydrocannabinol compounds have been meagre, and this is puzzling since there appears to be considerable interest in marihuana-type substances (see reviews by Solomon, 1967, and Andrews \& Vinenoog, 1968). The work described herein is a study of the effects of pyrahexyl, one of the marihuana homologues, on a conditioned emotional response (CER).
TROWILL, J. A., PANKSEPP, J., \& GANDELMAN, R. An incentive model of rewarding brain stimulation. Psychological Review, in press.
NOTE

1. This study was supported by USPHS Grant MH13155-02 awarded to Jay Trowill impressive difference in the mean latency to resume bar pressing in the one-trial extinction test. Mean latency for the pyrahexyl group $(\mathrm{N}=14)$ was $28 \mathrm{~min}$ $42 \mathrm{sec}$, while the control group $(\mathrm{N}=14) \mathrm{had}$ a mean latency of $53 \mathrm{~min} 53 \mathrm{sec}$. This difference is highly significant $(U=16$, $\mathrm{p}<.001)$ and is akin to that reported by Boyd, Hutchinson, Gardner, \& Meritt (1963). These investigators found that MOP, a methyl-octyl tetrahydrocannabinol derivative likewise disrupts the suppressive effects of a CS in the CER situation.

The possible sources accounting for the disruption of the CER are: (1) general activation of behavior, (2) interference with the inhibitory mechanism responsible for suppression, and (3) anxiety reduction. The first alternative is unlikely since Abel and Schiff 1 have found that pyrahexyl-injected animals are less active, not more active, than control animals in an open field. As to the second possibility, McGlothlin (1965) has noted that among humans there tends to be a reduction in social inhibitions following the use of marihuana, but this may be the result of increased suggestibility while under the influence of cannabis. With regard to the third hypothesis, there tends to be somewhat contradictory results in the human research: Pond (1948) reported that pyrahexyl induced a state of apprehension in his Ss, whereas Stockings (1947) noted a feeling of euphoria connected with the drug. The data from this experiment tends to support Stockings' findings; however, the final interpretation must await further experimentation.

REFERENCES

ADAMS, R., LOEWE, S., JELINEK, C., \& WOLFF, H. Tetrahydrocannabinol homologs with marihuana activity. Journal of the American Chemical Society, 1941, 63, 1971-1976.

ADAMS, R., HAEFENIST, M., \& LOEWE, S. NeW analogs of tetrahydrocannabinol. Journal of the American Chemical Society, 1943, 71, 1624-1628.

ANDREWS, $\mathrm{G}$, \& VINENOOG, $\mathrm{S}$. (Eds.), The book of grass. New York: Grove Press, 1968.

BOYD, E. S., HUTCHINSON, E. D., GARDNER, L. C., \& MERITT, D. A. Effects of tetrahydrocannabinols and other drugs on operant behavior in rats. Archives Internationales de Pharmacodynamie et de Thérapie, $1963,144,533-554$.

McGLOTHLIN, W. H. Cannabis: A reference. In D. Solomon (Ed.), The marihuana papers. New York: Signet, 1968.

POND, D. A. Psychological effects in depressive patients of the marihuana homologue synhexyl. Journal of Neurology, Neuro-Surgery, \& Neuropsy chiatry, 1948, 11, 271-279.

SOLOMON, D. (Ed.), The marihuana papers. New York: Signet, 1968.

STOCKINGS, G. T. A new euphoriant for depressive mental states. British Medical Joumal, 1948, 1,918-922. NOTE

\section{RESULTS AND DISCUSSION}

A Mann-Whitney " $U$ " test revealed no differences between groups in the rate of responding during the $6 \mathrm{~min}$ prior to the onset of the CS. However, there was an
1. Abel, E. L., \& Schiff, B. B. Unpublished observations.

2. This research was supported by Grant No. NRC APB 149. 